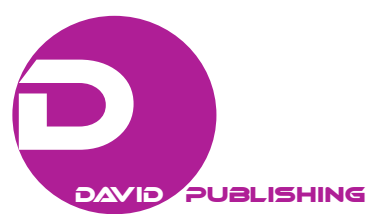

\title{
The “Metaphysical Physician” in Victorian Fiction: The Moonstone and A Romance of Two Worlds
}

\author{
Pritha Kundu \\ Cahandrakona Vidyasagar College, Medinipur, India
}

\begin{abstract}
The Victorian period experienced, among many other paradoxes, an ongoing tension between science and spirituality. Bearing the legacy of the "Enlightenment Rationalism” and the Cartesian division between "matter" and "mind" since the eighteenth century, the Victorian minds had to deal with a contemporary world rapidly unfolding new discoveries in geology, astronomy, biology, and medical sciences. However, these could not completely erase the spiritual belief from the human mind. Rather they sought to reshape their codes in terms of “alternative sciences” like occultism and metaphysical psychiatry (pre-Freudian). This paper seeks to explore the characterisation of the "metaphysical" physician in two novels by Wilkie Collins and Marie Corelli, showing how these figures play a crucial role in negotiating the tensions between science and spiritualism.
\end{abstract}

Keywords: occultism, alternative science, metaphysical physician

\section{Introduction}

The emergence of "alternative sciences" in the Victorian age was not a homogeneous phenomenon. In The Other World: Spiritualism and Psychical Research in England, 1850-1914, Openheim explains how, tormented by this "crisis of faith", many Victorian intellectuals were struggling to find a way of "synthesis(ing) modern scientific knowledge and time-honoured religious traditions concerning man, God, and the universe” (1985, p. 59). If the early decades of the Victorian period saw a trumpeting of progressive ideas like democracy, liberalism, positivism, and materialism, the later decades felt the pangs of uncertainty and disbelief about the new deity of "science". The need of the time, then, was reflected in the search for new, synthetic philosophies of religion that "could meet the specific demands of their day by satisfying a religious need in language, and through procedures, acceptable to science” (Openheim, 1985, p. 62). This tension behind an attempted symbiosis between science and spirituality betrays a perplexity and discomfort which can be read as the troubled Victorian unconscious. In a critical sense, "psyche” and "spirit” are not synonymous terms. However, they seemed to be overlapping in the imagination of the nineteenth century pseudo-scientists, regarding a shared distrust of "matter". Against this backdrop of an intellectual and cultural unease, the figure of the pre-Freudian psychiatrist emerges as a transitional character who hovers between the psychical and the spiritual.

\section{“Metaphysical Doctoring” in The Moonstone}

Collins' novel, The Moonstone (1868) depicts one such remarkable figure of a "metaphysical physician”.

Pritha Kundu, Assistant Professor, Cahandrakona Vidyasagar College. 
It begins as a mystery novel, focused on the theft of a precious Indian diamond, called "the Moonstone" presented to Rachel Verinder on her eighteenth birthday. Suspicion falls on several characters within and outside the family, including a mysterious group of three Indian priests who seek to restore the jewel to their sacred Deity. Rachel, later in a heated discussion with her former lover and cousin, Franklin Blake, reveals that she had seen him take the Moonstone from her drawer, and kept it as a painful and disgracing secret to herself. Blake cannot remember anything, and he does not know how to prove his innocence to Rachel. He loses faith in his honesty and is on the verge of psychosis. It is at this point that Dr. Ezra Jennings is introduced, and he gradually assumes importance as a friendly medical advisor to Blake. The most remarkable description of the character comes from Franklin Blake when he meets him for the first time:

His complexion was of a gipsy darkness; his fleshless cheeks had fallen into deep hollows, ... From this strange face, eyes, stranger still, ... dreamy and mournful, and deeply sunk in their orbits-looked out at you and ... took your attention captive at their will. (Collins, 1999, p. 299)

What this description offers is an image of "otherness" and disease- the latter produced by the effect of opium. Much has been said about the fraught relation between "opium" and "empire" since the time of De Quincey; and Jennings is an embodied symbol of both. A man of mixed Eurasian origin, born in the colonies, the drug-addict Ezra Jennings is a social outcast. The old butler Betteredge, a typical Victorian Englishman, does not like him, and even the lawyer Mr. Gruff, a professional man of reason and ability suspects Jennings' "metaphysical" methods of medical experiment. However, in a symbol-laden mystery novel like The Moonstone, his function finally proves to be the most "scientific" and able to unveil the "buried truth" (Prytz, 2012, pp. 3, 14) which other characters fail to find. There is an interesting paradox about this alienated man: His past is in the dark, and nobody cares for it since he is a "peripheral" character, yet he takes the most important role in throwing light on the distorted reality of suspicion and psychological suffering that surrounds the major characters in the novel. What we know is that he has escaped some dire punishment and come under the shelter of Dr. Candy, the local practitioner, well known to the Verinder family. By the time the romance between Franklin and Rachel is almost destroyed under a terrible burden of misled accusations, Dr. Candy has developed amnesia, in consequence of an acute pneumonic fever causing meningitis and a brain-failure. Almost an invalid, he is now under the caring treatment of his grateful assistant, Jennings.

Jennings has saved Dr. Candy's life following his own medical opinions, opposed by two other specialists. And during the post-recovery care-giving to the withered patient, he has developed an experimental method—verging on the psychical and even the "metaphysical"-which succeeds in deriving meanings from the delirious ramblings of Dr. Candy. Jennings has collected his broken words and by deduction, produced a convincing case-report of what happened at that fateful party-night of the previous year. Franklin learns that he actually took the jewel, not with any ill intention but out of a concern for its safety, in a tranced state of mind under the influence of opium. At the party, Franklin said that he would not trust any medicine, not even to get a relief from insomnia. Dr. Candy, insulted, secretly added a certain dose of opium in Franklin's drink, and meant to tell him later that he did so to cure his insomnia, which he took as a challenge. Unfortunately, his severe illness immediately after the incident prevented him to clarify things. Jennings, in order to redress the mistake committed by his patient and colleague, takes interest in the case of Franklin, using the same drug for a different purpose - to reconstruct the actions of the previous year and thus prove Franklin's innocence.

As a doctor-cum-patient, Jennings places his own case-history side by side with that of his patient. He 
suffers from nervous disease, and his excessive intake of opium is a means of alleviating his pains to make an otherwise withered life somewhat endurable. He loved someone, and there is no hope for reunion with her, yet he wishes to provide for that dear person before he dies. His self-sacrificial role as a benefactor to this unnamed beloved, and his equally selfless function as a "healer" of the emotional wounds of a damaged love suffered by Rachel and Franklin can be placed side by side to ask whether Franklin's psycho-pathological degeneration caused by a shattered love make him look like a mirror-image to the doctor. Jennings, as a doctor a lost lover and an alienated person, takes delight in playing a positive role in bringing remedy to another case of wounded love. And his ultimate self-sacrifice highlights his function as a "pharmakos" which bears the double connotation of "sacrifice" and "healing" through "purgation" in a ritualistic sense-that of maintaining the civic health in ancient Greece by sacrificing a "diseased” body. Another word, "pharmakon" derives from the same root, and this denotes "drug” "remedy" or "poison" (Derrida 1981, p. 71). Jennings can be associated with both words and their complex connotations - he is a drug-addict, but he also uses the drug to keep himself alive and to help others. He remains the "healer" up to the end: His self-sacrifice has restored Dr. Candy to normal health, saved the Verinder family from further tragic consequences. A few months before his death, his own narrative ends with a beatific sensation of "healing":

Oh me, how I felt as the grateful happiness looked at me out of [Rachel's] eyes, the warm pressure of her hand said, "This is your doing"!

My poor patients are waiting for me. Back again, this morning to the old routine...

God be praised for his mercy! I have seen a little sunshine—I have had a happy time. (Collins, 1999, p. 396)

\section{Spiritual Healing in A Romance of Two Worlds}

Collins' mid-nineteenth century mystery novels made much of the gothic and the occult, further popularised by the late Victorian authors like Rider Haggard and Marie Corelli, and in most cases the representative "occult" personality is characterised as someone ethnic and exotic. The role of an occult physician (who belongs to a mystical Eastern creed) in doctoring the sick, neurotic body and soul—-the diseased product of a decaying and internally fragmented Western civilisation, becomes significant in Marie Corelli's first novel, A Romance of Two Worlds (1887). This tells of a spiritual cure thorough the agency of a metaphysical physician, Heliobas, whose remedies for nervous and psychic ailments derive from the "Electric Creed" of Christianity. As the narrator elaborates, the "Electric Creed" seems to have some correspondence with contemporary science as well:

I knew that there were many cases of serious illnesses being cured by means of electricity ... and I saw no reason to be surprised at the fact of a man being in existence who had cultivated electric force within himself to such an extent that he was able to use it as a healing power. (Corelli, 1887, p. 80)

Corelli's depiction of such a "healer" is not without the scientific context of her time. The idea of the electric healing was not new in the Victorian age. In France, Mesmer had already used it in the 1770s in his clinic where patients had to undergo an electro-magnetic shower or bath in a specially designed setting for treatment. Almost a century later, in 1870, late Victorian scientists like Gustav Fritsch and Eduard Hitzig developed a neurological theory of electrical transmission within the cerebral cortex. Corelli directed such scientific findings towards an occult theory of "healing": her spokesperson Heliobas suggests such electrical transmission can occur not only within the cells of the human brain, but it can be exchanged between the 
Divine Brain (Godhead) and the human nervous system, as Stiles (2012, p. 158) aptly observes.

According to Heliobas' "Electric Creed”, God is a "Shape of pure Electric Radiance” whose appearance is always associated with "pure light" in the Scriptures. He offers his eight-step theory to prove that Christ was an "Embodied Electric Spirit". The star which guided the Magi to Bethelhem was a radiant electric flame, and the Eastern wise men recognised its significance because "electricity was an advanced science" for the Chaldean civilisation. The angels who appeared to adore the birth of Christ were "the Singing Children of the Electric Ring” created around the Central Spirit of Electricity (God) at the time of the Beginning (Corelli, 1887, p. 228). In this way, Corelli goes on to give Biblical proofs of the idea that "Christ was an embodied Electric spirit". The most remarkable, however strange, "proof" comes when Heliobas defines Christ's power to heal as an electrical exchange of "virtue". He explains that when a woman with a "long-standing ailment" touched Christ's robe, she was cured instantly, but Christ felt that some "virtue" was gone out of him- -which is the exact feeling that a physical electrician experiences at this day after employing his powers on a subject" (Corelli, 1887, p. 229). The easy equation between "virtue" and electric power transmitted from one source to another sounds too far-stretched, but if Gustav and Hitzig's theory of electrical signaling in neuro-transmisson can be accepted, Corelli's inspired blend of medical and spiritual healing seems to be successful as a literary device in a scientific "romance". ${ }^{1}$

Corelli's characterisation of Heliobas as influenced by mystical creeds like Rosicrucianism and Oriental religions like Buddhism has been discussed by several critics, but none perhaps has attempted to read the "spiritual" basis of his therapeutic activities in terms of Eastern medical philosophies. In order to convince the patient that her soul and that of Heliobas belong to the same circle of electricity, he urges her to "look steadily" at him, as he clasped her hand. The patient experiences something mysterious:

...I saw what might be termed the image of another face looking at me through or behind the actual form and face of Heliobas. And that other face was his, and yet not his; ... the face of a friend ...one that I must have loved in some distant time, for my whole soul seemed to yearn towards that indistinct haze where smiled the fully recognised yet unfamiliar countenance. (Corelli, 1887, pp. 94-95)

A psychoanalytic approach may read this passage in terms of the Freudian alter-ego or the Lacanian “mirror-image”. However, considering Corelli's interest in Buddhism and Heliobas' identity as an Oriental sage, one may also sense a resemblance with the "janmantar" or "jataka" concept in Buddhist philosophy. Basically "Jataka" is a concept of the transmigration of the soul (not exactly in the Pythagorian sense) across the recycling of birth and death, and Corelli's narrator uses the very word "soul-transmigration” (Corelli, 1887, p. 80) to describe the process of spiritual healing Heliobas brings to his patients. Jataka tells the stories of Buddha's previous descents into the world, revealing how the other souls related to him now had also been associated with him in previous birth-cycles. Through a vision of the previous cycles of birth Buddha used to bring a "healing effect" to the troubled minds that came to him for solace.

The reciprocal exchange of gaze between the master-healer and the patient (who later becomes almost an worshipper of Heliobas) is both aesthetically and spiritually charged: It is a kind of “darshan”, a concept in Indian aesthetics (also in spiritual philosophy) of mutually exchanged gaze between the adoring self and the subject of adoration (in a spiritual sense, the deity and the devotee). "Darshan", again, is one of the ways by which the healer in Ayurvedic tradition diagnoses, but this is different from the "medical gaze" authorised and

\footnotetext{
${ }^{1}$ See Stiles (2012), pp. 158, 184.
} 
clinicised in the west, since this observation invites the patient's agency as corresponding to the doctor's. The gaze is not limited to the doctor, and there are indeed techniques like "Tratak" or "Surya-darshan" as prescribed exercises good for both eyesight and spiritual strength that involve the patient's gaze, in several Yogic and ayurvedic practices of healing. The use of "sight" in indigenous healing traditions is often associated with sense-observation, but it can go beyond the mere senses as well.

At another level the role of the metaphysical physician can be read as a curious blend between the Shaman and the psychoanalyst. Drawing on Claude Levi-Strauss' cultural anthropology, Sudhir Kakar argues: “Both the Shaman and analyst establish a direct relationship with the patient's conscious and an indirect relationship with his unconscious - the analyst through listening, the shaman through oratory” (Kakar, 2012, p. 92). Like a shaman, a psychoanalyst also approaches the troubled mind of the patient enabling it to enter a different level of ritualistic or linguistic experience. This is exactly what Heliobas does with Celini and the female narrator. Ezra Jennings applies similar kinds of linguistic experiments with the disordered nerves of Dr. Candy, and later, listens to the revelation of the "truth" from the language and action of Blake, in a state of trance. If texts like The Moonstone and A Romance of Two Worlds are studied within an overdetermined context of cultural anthropology and its evolution across time and space, the figure of the half-Oriental occult physician appears to be all the more significant in the Victorian context of alternative sciences and interest in psychical exploration. The ethnic identity of Heliobas as a Chaldean occult scientist and that Ezra Jennings as an "alien” figure (who is finally able to reconcile himself to the English society around him, by assuming a role of a self-negating healer) seems to reinforce Gouri Viswanathan's observation:

... the otherworldliness of the occult offered alternative possibilities for imagining colonial relations outside a hierarchical framework, [...] In reimagining colonial relationships, occultism performs a function similar to what Robert Young describes as culture's role in imperializing Britain, which allowed for a cross-fertilization of language, history, and literature without the "racial” degeneration caused by sexual contact. (2000, p. 2)

\section{Conclusion}

Occultism in the nineteenth century Britain thus functioned as one of the aspects of interconnectivity between the sociological, political, cultural, and scientific issues of topical interest.

It is in this complicated scenario of "science and spiritualism" in the nineteenth century Europe, which the figure of the metaphysical physician assumed a cultural representativeness through their literary portrayal. Of course, the materialistic and empiricist distrust of such pseudo-sciences was strong at a time of increasing scientific and technological developments; yet the existence of a doubt-ridden, spiritually distraught subconscious underneath the positivist progress was unmistakable. While the utilitarian civilisation demanded a celebration of the public causes in society, the sufferings of the individual psyche struggled for expression. The metaphysical or occult physician in the literary gothic and popular romance in the nineteenth century can be understood as an "objective correlative" to the individual subject's desire to find a way of healing out of the "disease" of material life, negotiating the tensions within the tripartite conception of being (body, mind, and soul). The literary portrayal of such figures, in a sense, undermines an attempted symbiosis between science and spirituality which betrays the perplexity and discomfort of the troubled Victorian unconscious.

\section{References}

Collins, W. (1868/1999). The Moonstone. Hertfordshire: Wordsworth Editions Ltd.

Corelli, M. (1887). A Romance of Two Worlds. New York: WM. L. Allison Company. 
Derrrida, J. (1981). 'Plato’s Pharmacy’. Dissemination. (B. Johnson, Trans.). Chicago: University of Chicago Press.

Kakar, S. (1982/2012). Shamans, mystics, and doctors: A psychological inquiry into India and its healing traditions. New Delhi: Oxford University Press.

Openheim, J. (1985). The other world: Spiritualism and psychical research in England, 1850-1914. Cambridge: Cambridge University Press.

Prytz, R. (2012). “Ezra to the Rescue: Three Facets of Moonstone”. (Bachelors Degree Project, Stolckholm University). Retrieved from http://www.diva-portal.org/smash/get/diva2:550765/FULLTEXT01.pdf

Stiles, A. (2012). Popular fiction and brain science in the late nineteenth century. Cambridge: Cambridge University Press.

Viswanathan, G. (2000). 'The ordinary business of occultism'. Critical Inquiry, 27, 1-20. 